\title{
The Geographical Distribution of Australian Cave-Dwelling Chiroptera
}

\author{
By E. Hamilton-Smith ${ }^{1}$ )
}

With plates $20(1)-23(4)$

With the exception of faunal surveys relating to specific areas and some fragmentary reports in other papers or general textbooks, little attention has been paid to the geographical distribution of the Australian Chiroptera. Tate (1946) and Simpson (1961) have both discussed the group from the point of view of historical zoogeography, but with no reference to distribution within Australia. The present paper summarizes available data relating to the distribution of those species using caves as roosting sites. Only 22 of the 56 recorded Australian species are therefore dealt with here.

Although the taxonomy of Australian bats has been widely discussed, sub-specific and sometimes even specific taxa remain confused. Accordingly, sub-species are not considered in this paper and certain species have been grouped together. Nomenclature is in accord with the most recent literature, and where an alternative name has been widely used for the species in question, this is indicated in brackets. However, it is to be emphasized that this does not necessarily indicate that the names thus shown are synonyms.

The data summarized in this paper has been derived from examination of collections, from published data, and from banding or other observational reports. The latter are only included where there is no doubt of the accuracy of identification. For the purposes of this paper, mines and other tunnels have been regarded as ecologically equivalent to natural caves, although at best this may be a rough generalization. Localities referred to by name are indicated in Fig. 1, but in the more widespread species, a map of distribution has been included rather than a detailed list of place names.

\footnotetext{
1) 17 Helwig Ave., Montmorency, Victoria, Aust.
} 


\section{Family PTEROPIDAE}

The PTEROPIDAE are not generally cave-dwelling and many species roost during the day in positions where they are exposed to the direct rays of the sun. As most species are dependent upon normal ocular vision for their orientation during flight, they would indeed be quite unable to enter the dark portion of a cave. However, it has been established by Mohres\& Kulzer (1956) that certain species of the genus Rousettus are able to fly in complete darkness, using audible sounds to provide an echo-location system equivalent to the ultrasonic orientation of the Microchiroptera. One cave-frequenting species has been reported from Australia and is discussed below. It is not known whether this species is capable of flight in the dark sections of caves or whether is confined to the threshold zone and observations relating to this matter would be of the greatest interest.

Dobsonia moluccensis (Quoy \& Gaimard) 1830 (D.magna Thomas): Within Australia, this species appears to be restricted to Cape York Peninsula, from where it was first reported by Allen (1935). These and other specimens have been collected while feeding, but Tate (1952 a) and later collectors have taken specimens roosting in mine tunnels. In New Guinea this species, and others of the same genus, normally roost in caves, e.g., Van Deusen \& Peterson (1958).

An unidentified member of the family has also been reported from the Tunnel, in the Napier Range, Western Australia by both Jennings \& Sweeting (1963) and Marshall \& Drysdale (1962). It appears that this species is confined to the threshold zone but specimens and further data are needed to solve the problems posed by these reports.

\section{Family EMBALLONURIDAE}

Six described species of the genus Taphozous have been recorded in Australia. Of these, T. flaviventris Peters 1867, T. nudicluniatus De Vis 1905, and T.mixtus (Troughton) 1925 have not been collected from caves, although Tate (1941,1952a) reports the latter species as being cave-dwelling in New Guinea. Tate (1952a) has briefly discussed the taxonomy of the other three described species, but further clarification of their respective status is required. Accordingly, in this paper, the name T. australis Gould 1854 will be confined (perhaps wrongly) to the small form found in Northern Queensland, and all other records assigned either to T.georgianus Thomas 1915 or T. troughtoni Tate 1952 are considered together as Taphozous spp. Clearer differentiation is impossible at present, but it must be borne in mind that later discussion on the distribution of these species is dependent upon the above grouping. 
Taphozous australis Gould 1854: Recorded by Gould (1854) and Tate (1952 a) as roosting in sea caves in the sandstone cliffs of Albany Is., near Cape York. Troughton (1925) and Tate (1952a) list many other localities on Cape York Peninsula, while Tate also collected this species from Chillagoe Caves. Troughton considers Cardwell to mark the Southernmost habitat of this species.

Taphozous spp.: Bats variously ascribed to T. georgianus or to T. troughtoni are commonly found in caves or rock crevices across the Northern parts of the continent. Localities specifically recorded are shown in Fig. $2 \mathrm{~A}$, based upon data from Thomas (1915), Troughton (1925), Wood Jones (1925), Tate (1952 a), Douglas (1957), Ride (1959 and pers. commun.), Purchase (1962), Walsh (pers. commun.) and from specimens in the collections of the Australian Museum (Sydney), Queensland Museum, and South Australian Museum. This bat is reported by both Aitken and Walsh (pers. commun.) to be readily disturbed and unusually active during the day. It is often found in threshold areas of caves, but also enters the dark zone. From the map, it will be seen that two localities are recorded South of $28^{\circ} \mathrm{S}$, but both of these are only represented by a single specimen.

\section{Family MEGADERMATIDAE}

Macroderma gigas Dobson 1880 is the sole Australian representative of this family. Although not commonly seen, it has become. widely known through the many references to it in popular literature under the names of "ghost bat" or "false vampire bat!" It has been suggested that it is approaching extinction, but as Finlayson (1958) has pointed out, it is still comparatively widespread, although in apparently small numbers. Almost all records which detail the habitat of this species specify either caves, mines, or deep rock crevices as its roosting site. Its distribution is mapped in Fig. 2 B, based upon data from Waite (1900), Wood Jones (1925), Tate (1952a), Douglas 1957), Robinson (1957), Finlayson (1958), Ride (1959), Cook (1960 and pers. commun.), Butler (1961), Douglas (1962), Walsh (pers. commun.) and from specimens in the Australian Museum (Sydney) and the Queensland Museum. This species formerly enjoyed a wider range of distribution, as shown by the various sub-fossil occurrences in Southern Australia.

\section{Family RHINOLOPHIDAE}

Two species of this family have been recorded from Australia, one of which, Rhinolophus philippinensis Waterhouse 1843 (R.maros robertsi Tate) has only been collected on two occasions, although widespread throughout the islands to the North. It was first recorded by Tate (1952 b) from a mine near Cooktown, Queensland, and one further specimen, captured in flight near Cairns, is now in the C.S.I.R.O. collection (Canberra). 
Rhinolophus megaphyllus Gray 1834: This species is almost always found in mines, caves or tunnels. Recorded localities are numerous and are shown in Fig. 3 C, for which data was derived from the collections of the Australian Museum (Sydney) and the Queensland Museum; from Tate (1952 a), George and Wakefield (1961), Purchase (1962), Harrison (1962) and from the unpublished records of the Australian Bat Banding Scheme. It can be seen that this species is virtually confined to the Eastern Coastal region. Each of the sites Westward of the foothills of the Great Dividing Range are represented by only one specimen.

\section{Family HIPPOSIDERIDAE}

Of the six species of this family occurring in Australia, all have been suggested to be cave-dwelling, although in some cases this appears to be the exception rather than the rule. However, the data available on all members of the family is limited.

Hipposideros ater Templeton 1848 [H.bicolor (Temminck)]: This species has been thought to be confined in Australia to Cape York Peninsula, e.g., Tate (1952 a) but Johnson (1959) has shown that it also occurs in the Arnhem Land Region. Details of roosting sites are generally unknown, but Harrison (1962) records it from a cave near Cairns.

H.galeritus Cantor 1846 [H.cervinus (Gould)]: Gould described this bat from sandstone caves on Albany Is., near Cape York, while Tate (1952 a) records it from both mines and deserted dwellings. It has only been recorded in Australia from Cape York Peninsula.

H.diadema (Geoffroy) 1813: Specimens have been taken from Cape York Peninsula and as far South as Cardwell. In most cases the habitat is unrecorded, but Tate (1952a) and later collectors have obtained it from a mine at Iron Range.

H. semoni Matschie 1903: Most specimens of this bat have been taken in flight or in deserted buildings in the Cape York Peninsula, but one specimen provisionally referable to this species in the collections of the Australian Museum was collected from a mine at Mt. Isa.

H.stenotis Thomas 1913: Described from specimens collected by Dahl in "caves" along the Mary River in Arnhem Land, although these are unlikely to be more than shallow rock-shelters.

Rhinonicteris aurantius (Gray) 1845: Few specimens of this bat have been collected, although Wood Jones (1925) describes it as being widely though sparsely distributed throughout the Northern Territory and the Northern part of South Australia. Specimens in the Australian Museum collections have been taken from caves near Katherine and Walsh (pers. commun.) reports that these caves contain a very large colony of this species during the wet season. This population leaves the caves during the dry season, and although it might be suggested that this is a maternity colony, this is unconfirmed. 


\section{Family MOLOSSIDAE}

Members of this family are commonly cave-dwelling in other parts of the world and many writers on Australian bats have stated that at least some of our five species are also cave-dwellers. However, there is no authentic record of any of these species being found in a cave. Allen (1939) comments upon the readiness of this family to colonize buildings, and this has occurred commonly in Australia, while specimens are commonly found in hollow trees. The habit of nestling into narrow cracks may mean that cave-dwelling individuals have escaped notice.

\section{Family VESPERTILIONIDAE}

Two species normally roosting in buildings or hollow trees have both been reported from a cave at Jenolan, N.S.W. by Dew (pers. commun.). These are Pipistrellus tasmaniensis (Gould) 1858 and Nycticeius orion (Troughton) 1937. Details of other species known to be cavedwelling follow.

Myotis adversus Horsfield 1824 (M.macropus Gould): This species appears to be sparsely distributed. It has been reported from caves at Narrengullen, N.S.W. by Purchase \& Hiscox (1960), at Buchan, Victoria by George and Wakefield (1961) and from caves on the Glenelg River by McKean (pers. commun.). A single specimen in the C.S.I.R.O. collections has been taken from a railway tunnel near Brisbane. Other specimens have been taken in flight, or in buildings.

In considering the genus Chalinolobus some records are of doubtful authenticity. George \& Wakefield (1961) report the misidentification of Miniopterus schreibersi as a member of this genus. Specimens of both $C$. Gouldi and $C$. morio in the Australian Museum collections labelled "Belubula Caves" were probably taken from the surface in the vicinity of these caves, now known as the Cleifden Caves.

Accordingly, authentic records can only be cited for two species as below.

C.picatus (Gould) 1852: The individuals currently referable to this species present a wide range of variation, but two records exist from mine tunnels. The first is a single nursing female with young taken from a mine near Broken Hill by Aitken (S. Aust. Museum) and the second a small maternity colony recorded by Dwyer (pers. commun.) from a mine near Copeton, N.S.W.

C.morio (Gray) 1841: This species is commonly tree-dwelling throughout the continent, but has been demonstrated by recent collections to be one of the dominant cave-dwelling species in parts of Western and South Australia. Recorded occurrences in caves as represented by specimens in the W. Aust. 
Museum, S. Aust. Museum, and C.S.I.R.O. collections are shown in Fig. 4. It will be noted that few records of other species occur in the areas concerned.

Eptesicus pumilus (Gray) 1841 (Vespadelus pumilus): This widely distributed species exhibits wide variation, both morphologically and from a point of view of habits, and may prove to be divisible into more than one species. Its preferred habitat varies from being apparently exclusively treedwelling in certain areas to being commonly cave-dwelling in others or to preferring to roost in buildings. Further, it may be solitary or gregarious in habit. In so far as any pattern can be discerned at this point, it is often cavedwelling in the Northerly parts of the continent (see Fig. 4), tree-dwelling in the Southerly parts of the mainland, and gregarious in buildings in Tasmania. Further investigation may show this pattern to be based upon temperature of the environment.

A number of erroneous records have been quoted for this species as a result of misidentifications or wrong data. Two which have been published warrant attention here. Sharland (1962) describes this species as cavedwelling, but in fact, no specimen has yet been recorded from a Tasmanian Cave. George \& Wakefie]d refer to a doubtful record from Buchan, Victoria. On examination of the records of the Victorian Cave Exploration Society (unpublished), the specimen (which has since been lost) is described as being larger than Rhinolophus megaphyllus. This suggests Miniopterus schreibersi which commonly occurs in the cave concerned, but certainly not E.pumilus.

The known cave occurrences are shown in Fig. 4, the data of which has been derived from Douglas (1957), Purchase (1962), Tate (1952a), Dwyer (pers. commun.), Ride (pers. commun.), and from specimens in the W. Aust. Museum, S. Aust. Museum, National Museum (Melbourne) and Australian Museum (Sydney).

Nyctophilus geoffroyi Leach 1822: This and the other members of the genus are typically tree-dwelling, but one specimen has been taken from Koonalda Cave, Nullarbor Plains (S. Aust. Museum) and Ride and Douglas (per. commun.) have obtained specimens from crevices in the rood of the Mammoth Cave, Margaret River, W.A. Occasional dead specimens of skeletal material are found in caves, e.g. Purchase (1961) reports a group of approximately 50 skeletons from the Coppermine Cave, Yarangobilly, N.S.W.

Miniopterus schreibersi (Kuhl) 1819 [M.blepotis (Temminck)]: This widely distributed species occurs in Australia along the whole of the Eastern Coastal Region, extending along the Southern Coast to Adelaide and the Southern Flinders Ranges (Wood Jones 1925) and along the Northern Coast to Broome (Ride - pers. commun.). The Southern-most locality recorded to date is a group of approximately 100 individuals banded by the author at Cape Liptrap, Victoria. Recorded cave occurrences are shown in Fig. 3 A, based upon the above records and Tate (1952 a), Purchase (1962), unpublished records of the Australian Bat-banding scheme, and specimens in the collections of the Queensland Museum and Australian Museum (Sydney).

The results of the Australian Bat-banding Scheme, partly reported by Dwyer (1963b) indicate that the population of this species is dependent upon a comparatively small number of maternity colonies, each of which serve a large area. Accordingly these are shown on the Figure. It has been established that these populations are not completely discrete, and that a small number of individuals more from one population to another, but this 
is unusual. The species is rarely found otherwise than in a cave, and it appears that the presence of suitable caves, especially those suitable to act as a maternity colony, may have some control over the distribution of the species.

The species discussed by Morrison (1959) as M.schreibersi appear to be, in fact, M.australis, as the body weight of the former species is generally in excess of 12.5 gms., and so for the purposes of this paper, Morrison's species is treated as M.australis.

Miniopterus australis Tomes 1858: This species, similar in morphology and habits to the former, occurs through the Northern part of the Eastern Coastal Region, with the Southern-most limit of its range in the Kempsey area, N.S.W. Known localities, as recorded by Tate (1952 a), Purchase (1962), Morrison (1959), and specimens in the Australian Museum (Sydney) are shown in Fig. $3 \mathrm{~B}$.

\section{Discussion}

Although the data summarized above is obviously incomplete, and at times indicating the need for further taxonomic certainty, it is possible from this to group the Australian species occurring in caves into four different groups. Little attention has been paid to the question of why certain species of bats choose to enter caves in preference to other forms of shelter. Some attention is therefore paid in the following discussion to hypotheses regarding the habits of the species concerned.

Group I species - those confined in Australia to the Cape York Peninsula and to Arnhem Land (Southern limit of range $18^{\circ} \mathrm{S}$. Lat.).

Dobsonia moluccensis,

Taphozous australis,

Rhinolophus phippinensis,

Hipposideros ater,

$H$.galeritus,

H. diadema,

H. semoni,

H. stenotis.

All of these except the last have been also recorded, most of them being widespread, in the islands to the North of Australia. The restriction of $T$. australis to this area may prove erroneous, as pointed out earlier, when more taxonomic clarity is arrived at in this genus. Similarly, the last species is only tentatively distinct from H.semoni and examination of further material may show this not to be a good species.

This group consists of a number of specimens of tropical habitat, restricted by this to a small portion of the Australian Continent. Their occurrence in this country is limited, and any study of their distribution is largely dependent upon details of extra-Australian records. 
Group I I species - found extensively throughout the desert and semi-tropical areas North of $28^{\circ} \mathrm{S}$. Latitude.

Taphozous spp.,

Macroderma gigas,

Rhinonicteris aurantius.

The recorded distribution of the two most widely distributed of these species is shown in Fig. 2. R.aurantius has not been included in this figure, as apart from the very large colony recorded in the Katherine Caves, few have been captured and the data available on these is inadequate. All species in the group have apparently adapted successfully to desert or semi-desert conditions, and are found not only the hottest areas of the continent, but in those subject to the greatest extremes in temperature variation throughout the day. The group is also of interest in that Macroderma and Rhinonicteris are the only two completely endemic Australian genera. Further study of these species is needed, and might well investigate the adaption to climatic conditions developed in these species, of which cave-dwelling is probably part.

Historical changes in the distribution of Macroderma have been the subject of considerable discussion since Wood Jones (1925) suggested its extinction in South Australia was due to increasing aridity. Butler (1961) in reporting a living specimen from one of the most inhospitable areas of the Western Australian desert postulated that the reverse was true, and that it had only been present in South Australia during periods of greater aridity. However, in view of the wide range of the species shown in the present paper, including many areas which are far from being arid, it would appear that neither of these suggestions are valid. The only climatic factor which may have any significance is that of temperature, and we have insufficient data on which to suggest any hypothesis at this point. However, attention can be drawn to the fact that in Southern and South-Western Australia it was apparently associated with a smaller bat in considerable colonies which have also disappeared. Being a large predaceous species, the population could easily be exterminated in a specific area by any significant change in its food supply, and this could be related to the general decrease in the number of smaller mammals reported by many workers, including Marlow (1959), Finlayson (1961) and Wakefield (1963).

Group I I s pecies - primarily distributed throughout the Eastern Coastal Region.

Rhinolophus megaphyllus, Miniopterus schreibersi, M.australis. 
Fig. 3 shows clearly the extent to which species of this Group are concentrated along the Eastern Coastal area, although M.schreibersi has a slightly wider range. Although this area presents a wide range of absolute temperature conditions, it will be noted that it falls within the area having a minimum of $20^{\prime \prime}$ of rainfall per annum, and a moderate range of variation in temperature. This suggests that these species may require a climate of reasonable humidity and without extreme variation in temperature.

However, an alternative hypothesis, already mentioned in outlining the distribution of M.schreibersi is that the presence of suitable limestone caves provides the significant factor in this distribution. It is certainly true that the caves inhabited by the species in Group II are, on the whole, much smaller and more shallow than those found in the limestones of the Eastern Coast. All three of these species appear to be found only in comparatively deep caves or in mine tunnels, as individuals captured from other habitats are extremely rare. Dwyer (1963c) has suggested that the presence of caves which can provide for the development of a high temperature within a maternity colony is essential for the effective reproduction of M.schreibersi, and further observation has served to confirm this suggestion.

Both hypotheses fail to explain the fact that this species has not moved further Westward along the South Coast of the continent, as this area enjoys similar climatic conditions in many sections, and certainly offers suitable caves. However, further study of the biology of this species which is currently proceeding may elucidate this problem, as may comparison with the extra-Australian distribution of the species.

Dwyer (1963a) has shown that the more restricted range of M.australis can be attributed to its reproductive cycle being less adapted to temperate conditions than that of M.schreibersi. No study has yet been made of the biology of Rhinolophus megaphyllus. However, present data on the movements of this species suggest that it does not make extensive journeys from maternity colonies as does Miniopterus, and the much greater distances between caves Westwards of its present range might be suggested as the factor preventing its further distribution.

Group IV species - widely distributed species, generally treedwelling, but found in caves occasionally, or only over part of a species range.

Pipistrellus tasmaniensis,

Myotis adversus,

Chalinolobus picatus, 
C.morio,

Eptesicus pumilus,

Nycticeius orion,

Nyctophilus geoffroyi.

Some species in this group appear to use caves only incidentally, and so cave-dwelling is of little significance here. Myotis adversus is a rare species, although widely distributed, and when recorded, this is often from a cave. However, its rarity precludes any general hypothesis regarding its distribution at this point.

C.morio and E.pumilus are both commonly cave-dwelling over certain sections of their range, although also found in trees or buildings in the same areas. Their distribution as cave-dwellers is shown in Fig. 4 and this map indicates interesting trends. In the case of C.morio, it appears to be cave-dwelling only in those areas where no other cavedwelling species lives and it could be suggested that it only occupies this niche in the absence of competing species. E.pumilus, on the other hand, will commonly share caves with other species, but this habit seems restricted to the Northern section of its range, and may well be related to climatic factors. It may be possible to test this experimentally, following the collection of further data regarding its use of caves and the conditions in these caves.

This paper sets down the present knowledge regarding the distribution of bats in Australian Caves, and presents some hypotheses regarding this habitat. It clearly indicates the need for more detailed observations upon the bionomics of all species, as well as experimental studies upon the adaption of each species to environmental conditions. Similarly, further study of bone deposits with a view to elucidating the historical distribution of these species should be undertaken. It is suggested that the habit of cave-dwelling is regulated by a variety of factors, but that the choice of caves in relation to other dark habitats is probably related to the climatic environment so provided. However, in M.schreibersi and possibly in other species of the same group, it is hypothesed that this is due to the cave providing an environment in which favorable conditions can be developed, rather than one in which the right conditions are pre-existing. In C.morio, it is suggested that this species only enters caves in the absence of other cave-dwelling species. 


\section{SUMMARY}

Of the 56 species of bats currently recorded from Australia, 22 are known to occur in caves. The geographical distribution of each of these species is detailed, and from this data, the species are divided into four groups according to their pattern of distribution.

Group I comprises those species found only North of $18^{\circ} \mathrm{S}$ latitude, all of which either also occur in New Guinea or are closely related to New Guinea species. Group II, including both endemic Australian genera, occurs over that area North of $28^{\circ} \mathrm{S}$ latitude. This area largely comprises desert or semi-desert terrain, with its characteristics of low humidity and a wide range between extremes of temperature.

Group III occurs in the Eastern Coastal Region, with one species extending to a limited degree along both Northern and Southern Coasts. Although temperature is extremely varied over this range, there are common environmental factors of moderate to high humidity and a moderate to low range of temperature variation. Group IV species are all widespread, in many cases over the whole continent, are all members of the Vespertilionidae, and occur in caves only occasionally or only in certain parts of their range. These species are more commonly found in trees or buildings.

The possible factors contributing to the origin of these distributional patterns are discussed, and some areas for future investigation suggested.

\section{RÉSUMÉ}

56 espèces de Chauves-Souris sont généralement citées d'Australie. La répartition géographique des 22 espèces signalées dans les grottes est étudiée en détail. Ces espèces sont, à partir de ces données, réparties en 4 groupes suivant leur type de distribution.

Le groupe I comprend les espèces trouvées seulement au $\mathrm{N}$ du $18^{\circ}$ de latitude $\mathrm{S}$; toutes sont soit présentes en Nouvelle-Guinée, soit étroitement apparentées à des espèces de cette île.

Le groupe II, renfermant les 2 genres endémiques australiens se rencontre au $\mathrm{N}$ du $28^{\circ}$ de latitude $\mathrm{S}$. Cette zone est en grande partie constituée de terrains désertiques ou semi-désertiques, avec comme caractéristiques une faible humidité et de grands écarts entre les températures extrêmes.

Les espèces du groupe III se rencontrent dans la région côtière orientale; l'une d'elles s'étend, jusqu'à un certain point, le long des côtes septentrionales et méridionales. Bien que les températures soient extrêmement variées sur ce territoire, il existe des facteurs de milieu communs : humidité moyenne ou élevée, variations de la température modérées ou faibles.

Les espèces du groupe IV sont largement répandues, sur tout le continent dans de nombreux cas; toutes sont des Vespertilionidae et ne se rencontrent dans les grottes qu'accidentellement ou que dans certaines zones de leur aire de répartition; ces espèces se trouvent généralement dans les arbres ou les constructions.

Les facteurs susceptibles de contribuer à l'origine de ces types de distribution sont passés en revue et il est proposé quelques domaines pour de futures recherches. 


\section{ACKNOWLEDGEMENTS}

The author accepts full responsibility for any errors in this paper, either of commission or omission, and for the opinions expressed. However, a paper such as this has only been made possible by the willing co-operation of the many people who generously gave the author access to specimens and-or data. In particular, special thanks are due to Dr. W. D. L. Ride, R. Mark Ryan, J. Calaby, P. D. Dwyer, and D. Purchase, all of whom read the first draft of the manuscript and made many valuable suggestions, and to L. Hall, who prepared the figures.

\section{REFERENCES}

Allen, G. M. (1935) - A fruit bat, Dobsonia, new to Australia. Aust. Zool., 8,151 .

- (1939) - Bats. Harvard University Press, 368 pp.

Butcer, W. H. (1961) - Occurrence of the Ghost Bat, Macroderma gigas, in the Great Victoria Desert, W.A. W. Aust. Nat., 8, $42-3$.

Соок, D. L. (1960) - Some mammal remains found in caves near Margaret River. W. Aust. Nat., 7, 107-8.

- (1963) - The fossil vertebrate fauna of Strong's Cave, Boranup, Western Australia. W. Aust. Nat., 8, 153-62.

Douglas, A. M. (1957) - A recent Western Australian record of the Ghost bat (Macroderma gigas). W. Aust. Nat., 5, 140-1.

- (1962) - Macroderma gigas saturata (Chiroptera, Megadermatidae). A new sub-species from the Kimberley Division of Western Australia. W. Aust. Nat., 8, 59-61.

Dwyer, P. D. (1963a) - Reproduction and distribution in Miniopterus (Chiroptera). Aust. J. Sci., 25, 435-6.

- (1963 b) - Bat Banding. Aust. Nat. Hist., 14, 198-200.

- $(1963 \mathrm{c})$ - The breeding biology of Miniopterus schreibersi blepotis (Temminck) (Chiroptera) in North-Eastern New South Wales. Aust. J. Zool., 11, 219-40.

Finlayson, H. H. (1958) - Recurrence of Macroderma gigas Dobson. Nature, 181, 923.

- (1961) - On Central Australian Mammals iv. The distribution and status of Central Australian species. Recs. S. Aust. Mus., 14, 141-91.

George, G., \& Wakefield, N. A. (1961) - Victorian Cave Bats. Vict. Nat., $77,294-302$.

Gould, J. (1854) - Mammals of Australia III.

Harrison, J. L. (1960) - Mammals of Innisfail I. Species and distribution. Aust. J. Zool., 10, 45-83.

Jennings, J. N., \& Sweeting, M. M. (1963) - The Tunnel, a Cave in the Napier Range, Fitzroy Basin, Western Australia. Trans. C.R.G., 6, 53-68.

Johnson, D. E. (1959) - Four new mammals from the Northern Territory of Australia. Proc. Biol. Soc. Wash., 72, 183-8.

Marlow, B. J. (1958) - A survey of the marsupials of New South Wales. C.S.I.R.O. Wildl. Res., 3, 71-114. 
Marshall, A. J., \& Drysdale, R. (1962) - Journey among mem. Hodder \& Stoughton, London.

Mohres, F. P., \& Kulzer, E. (1956) - Über die Orientierung der Flughunde• Zeitschr. f. vergleichende Physiologie, 38, 1-29.

Morrison, P. (1959) - Body temperatures in some Australian Mammals. Biol. Bull., 116, 484-97.

Purchase, D. (1961) - Note on the skeletons of lesser long-eared bats (Nyctophilus geoffroyi) found in the Coppermine Cave at Yarangobilly, N.S.W. Neswsletter Canberra Speleo. Soc. (roneoed) Apr. 1961.

- (1962) - A second report on Bat-banding in Australia. C.S.I.R.O. Aust. Wildl. Res. Tech. Pap., 2, 16 pp.

Ride, W. D. L. (1959) - A museum expedition to the Hamersley Range. Aust. Mus. Mag., 13, 94-8.

Robinson, A. (1957) - The Ghost bat in the North-West. W. Aust. Nat., $5,232$.

Sharland, M. (1962) - Tasmanian Wild Life. Melbourne University Press, $86 \mathrm{pp}$.

Simpson, G. G. (1961) - Historical Zoogeography of Australian Mammals. Evolution, 15, 431-46.

Tate, G. H. H. (1941) - Results of the Archbold Expeditions No. 37. Notes on Oriental Taphozous and allies. Amer. Mus. Novit., 1141, 1-5.

- (1946) - Geographical distribution of the bats in the Australasian Archipelago. Amer. Mus. Novit., 1323, 1-21.

- (1952 a) - Results of the Archbold Expeditions No. 66. Mammals of Cape York Peninsula, with notes on the occurrence of rain forest in Queensland. Bull. Amer. Mus. Nat. Hist., 98, 563-616.

- (1952 b) - Results of the Archbold Expeditions No. 67. A new Rhinolophus from Queensland (Mammalia, Chiroptera). Amer. Mus. Novit., 1578, 1-3.

Thомаs, O. (1915) - Notes on Taphozous and Saccolaimus. Journ. Bombay Nat. Hist. Soc., 44, 57-63.

Troughton, E. Le G. (1925) - A revision of the genera Taphozous and Saccolaimus (Chiroptera) in Australia and New Guinea, including a new species, and a note on two Malayan forms. Recs. Aust. Mus., 14, 313-39.

Van Deusen, H., \& Peterson, R. (1958) - Chiroptera of New Guinea. Nat. Hist., 67, 452-9.

Warte, E. R. (1900) - Recurrence of Macroderma gigas Dobson. Recs. Aust. Mus., 3, 188.

Wakefield, N. A. (1963) - Sub-fossils from Mount Hamilton, Victoria. Vict. Nat., 79, 323-30.

Wood Jones, F. (1925) - The Mammals of South Australia III. Government Printer, Adelaide, 381-449. 
EX PLANATI ONS OF PLATES 20 (1)-23(4)

Fig. 1: Map of Australia, showing localities referred to in paper.

Fig. 2A: Recorded occurences of Taphozous spp.

Fig. 2B: Recorded occurences of Macroderma gigas.

Fig. 3: Distribution of group III species, showing $20^{\prime \prime}$ isohyet and line of $50^{\circ} \mathrm{F}$. annual range of temperature variation.

Fig. 4: Cave occurences of two group IV species. 


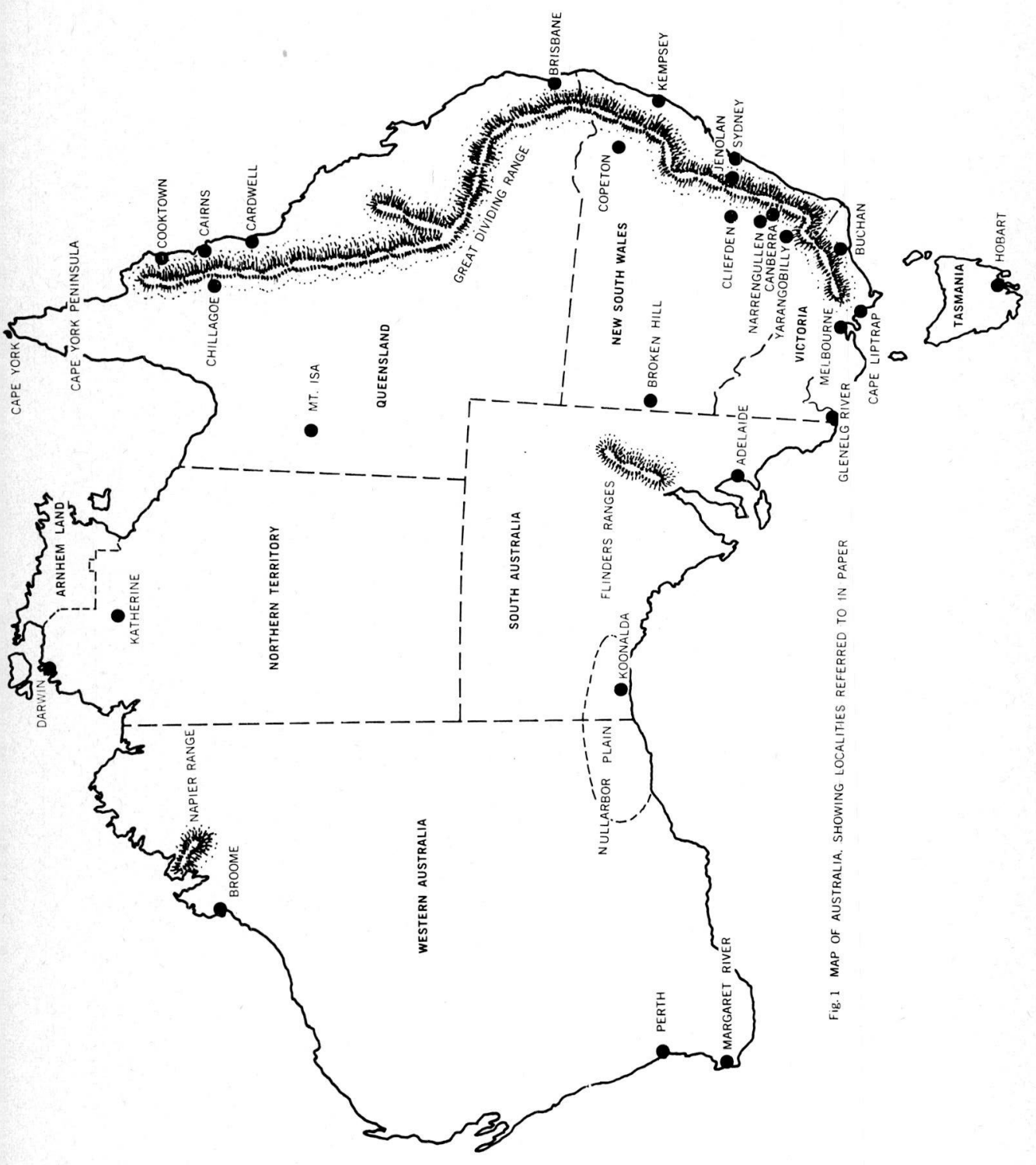



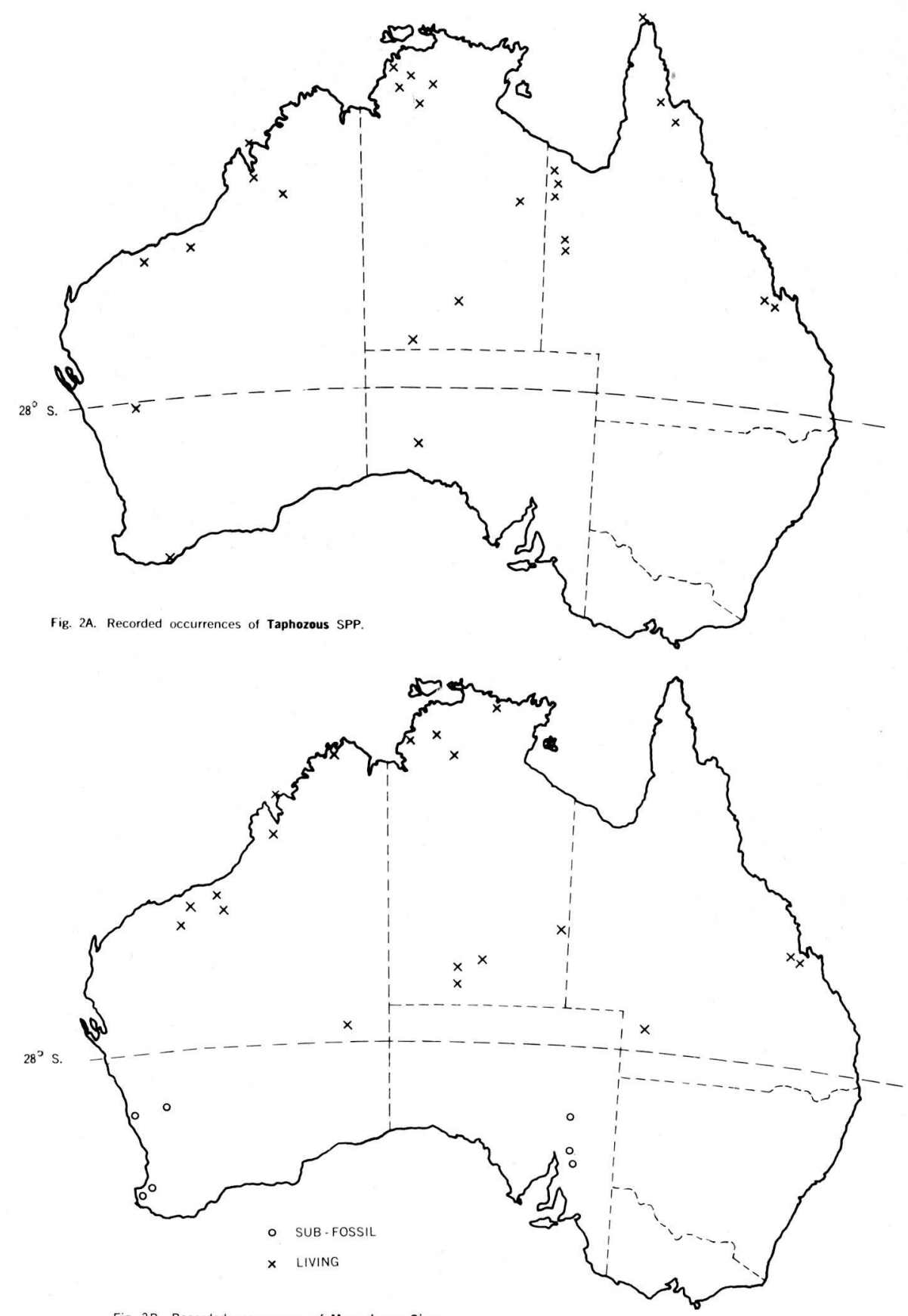

Fig. 2.B Recorded occurrences of Macroderma Gigas. 


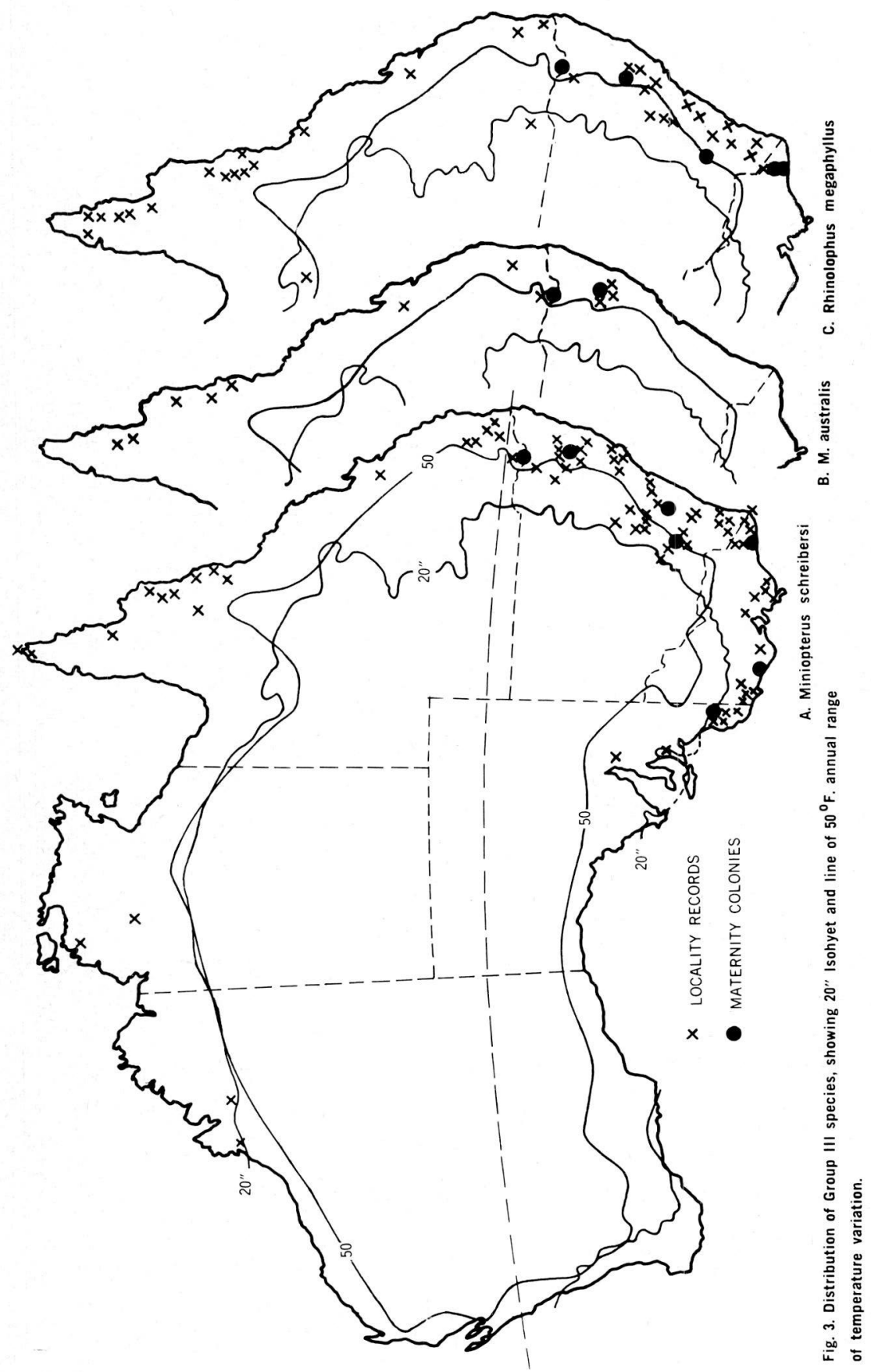




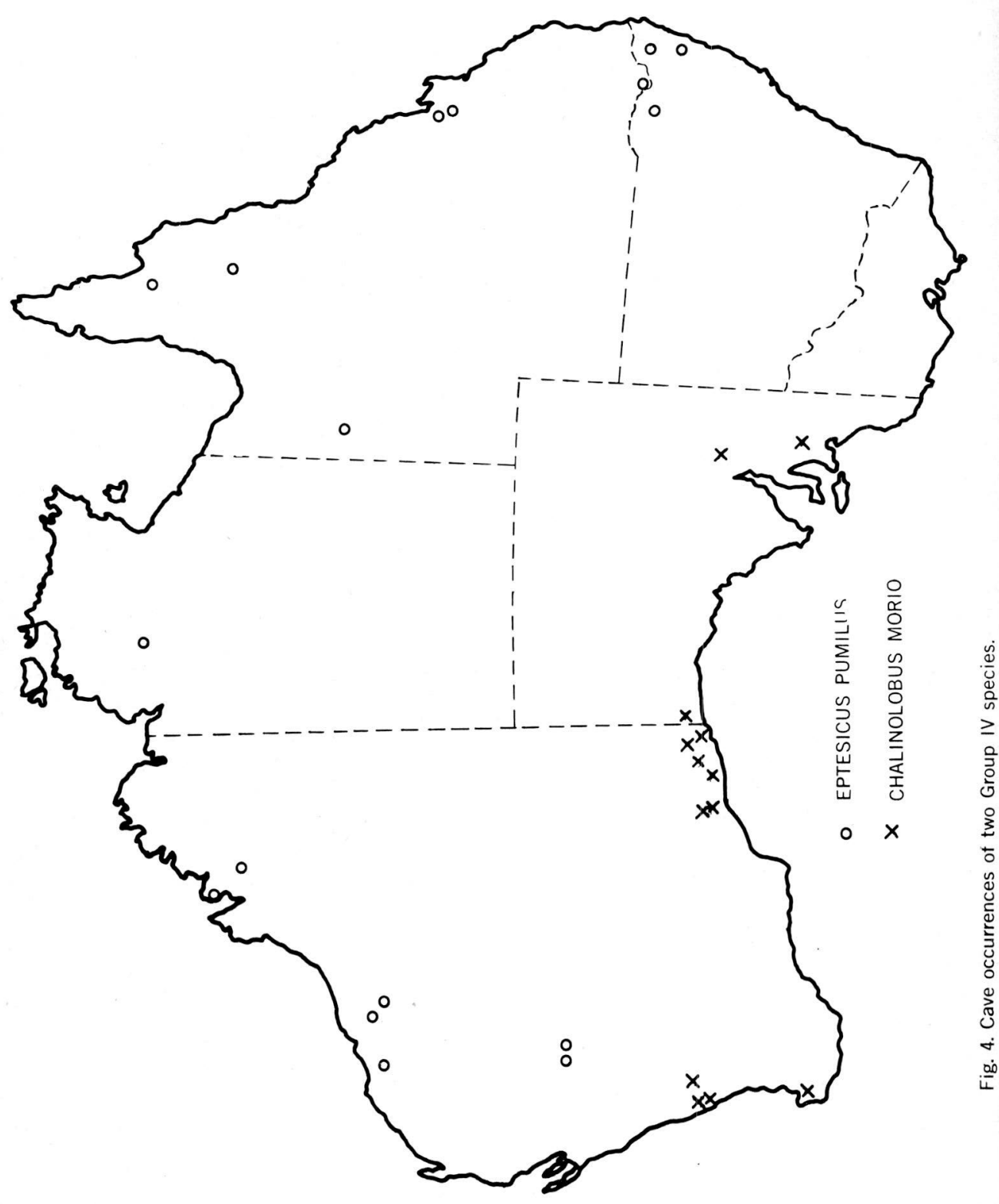

